\title{
KOMUNIKACIJA I POVRATNE INFORMACIJE IZMEĐU UČENIKA, NASTAVNIKA I RODITELJA
}

\section{Sažetak}

Rad je posvećen analizi komunikacije između nastavnika $i$ učenika s jedne, te roditelja s druge strane. Iz ove analize se nameću pitanja kako poboljšati komunikaciju među glavnim akterima obrazovnog procesa $i$ kako aktivnije uključiti roditelje u nastavni proces. Dosta je razloga koji utiču na uspostavljanje kvalitetne komunikacije. Efektivna vrijednost komunikacije može se postići tek onda kada sagovornici, odnosno akteri komunikacije, pri razmjeni informacija, prvenstveno razmišljaju o važnosti onoga što govore, o uticaju rečenog na sagovornike kao $i$ o nivou uspostavljanja obostranog razumijevanja za različite stavove $i$ mišljenja. Početni nivo stručne edukacije za pravilno komuniciranje svakako počinje kroz školovanje, ali onaj važniji $i$ uticajniji nivo za razvoj kulture komunikacije kod djece je svakako porodica. U cilju boljeg uvida $i$ razumijevanja stanja u našim školama, provedeno je anketno istraživanje čije rezultate autor daje pregledno u tabelama. Važan nalaz ovog istraživanja je da postoji potreba za većim sudjelovanjem roditelja u nastavnom procesu. Također, istraživanje indicira da je potrebna veća saradnja nastavnika sa roditeljima kao i bolja saradnja i komunikacija između nastavnika i učenika. Na kraju, istraživanje je korisno $i$ za nastavnu praksu, olakšava pedagozima i psiholozima detektovanje problema u školstvu $i$ otvara niz pitanja za dalje istraživanje i djelovanje.

Ključne riječi: komunikacija, povratna informacija, efektivna vrijednost informacije

\section{Uvod}

Đačko doba je najljepše doba u kojem stičemo prve simpatije, prva saznanja o svijetu, prva dokazivanja, takmičenja.. Ali, dešava se da neka djeca doživljavaju školu kao pravu mučionicu. Zašto je to

\footnotetext{
${ }^{1}$ Islamski pedagoški fakultet u Bihaću
} 
tako? Jedan od razloga može upravo biti uzrokovan nedostatkom kvalitetne komunikacije i razumijevanja između nastavnika i učenika, a značajnu ulogu u ovim interakcijama svakako imaju i roditelji, za koje možemo reći da su prvi učitelji. Cilj nastavnika ne bi trebao biti samo da servira informacije učenicima koji ih mehanički reprodukuju. $\mathrm{Ne}$ možemo reći za nastavnika da je uspješan, ako podučava nezadovoljnu djecu; ili, za đaka ne možemo reći da je potpuno uspješan, ako su odnosi i ako je saradnja sa nastavnicima i roditeljima veoma loša ili nikakva; roditelji nisu uspješni, ni sretni, ako njihovo dijete nije zadovoljno, sretno, ako se ne veseli svakom novom školskom danu. Škola treba da bude intelektualna i kreativna oaza, i kao odgojno - obrazovana ustanova u cilju razvijanja partnerskih odnosa sa roditeljima treba da permanentno radi na uspostavljanju kvalitetne komunikacije sa roditeljima. Zašto? Zato što se danas veliki akcent stavlja na uključivanje roditelja u sve vidove odgoja i obrazovanja koji se prožimaju kroz školu. Poznata nam je činjenica da su roditelji neizostavno bitni resursi kada je u pitanju odgajanje i obrazovanje djece. Međutim, i njih treba edukovati i usmjeriti ka pravilnom pristupu školi i sudjelovanju u školskim aktivnostima. $\mathrm{Na}$ koji način? Razvojni tim škole treba provesti istraživanje sa roditeljima i nastavnicima i na osnovu dobivenih rezultata kreirati bitne segmente kroz koje bi se prožimala saradnja i komunikacija sa roditeljima i na osnovu kojih bi se roditelji usmjeravali i uključivali u sve aktivnosti kroz koje je data mogućnost njihovog doprinosa. $\mathrm{Na}$ osnovu identifikovanih segmenata, škola treba kreirati plan uspostavljanja kvalitetne komunikacije sa roditeljima (Brajša, 1993.). Cilj ovog istraživanja je bio provjeriti stanje u našim školama, da se utvrde razlozi (manjka) saradnje roditelja sa školom i obratno, te snalaženje učenika u toj trijadi odnosa nastavnik-roditelj-učenik.

\section{Definicija komunikacije}

Komunikacija podrazumijeva prijenos znanja, misli, emocija, iskustava, stavova, informacija, razumijevanje misli između ljudi, s ciljem da se ostvari efikasno općenje. Da bi uspješno komunicirali, potrebno je da ostvarimo uslove, ne samo što se sadržaja tiče, već i odnosa među onima koji uzajamno komuniciraju. Komunikacija (lat. communicatio-saopćavanje, saopćenje, veza, ophođenje, općenje, dodir, saobraćaj) je, najjednostavnije rečeno, razmjena informacija ili 
stavova sa nekim. Postoji čak preko 250 različitih definicija komunikacije, što govori o važnosti i kompleksnosti ovog fenomena. Američki socijalni psiholog Kooley je još 1909. godine dao jednu od prvih i opširnijih definicija komunikacije, po kojoj je komunikacija mehanizam pomoću kojeg ljudski odnosi egzistiraju i razvijaju se, a sačinjavaju je svi simboli duha sa sredstvima njihovog prenošenja kroz prostor i očuvanja u vremenu. Svaku komunikaciju prate izrazi lica, stav, gestovi, mimika... Šta je feedback?

Feedback je tip komunikacije koji čovjek prima ili daje. On je način putem kojeg se čovjeku pokušava dati do znanja koliko je efektivan u onome što radi i u onome što pokušava obaviti, te kako utiče na onog ko mu upućuje feedback. Feedback također pomaže čovjeku da nauči kako postati efektivniji u onome što radi, te ga upućuje u njegov uticaj na svijet oko njega.

Postoje dvije osnovne vrste komunikacije: verbalna (odvija se uz pomoć riječi i rečenica) i neverbalna (uz pomoć gestova, mimike, intonacije, pokreta tijela, facijalne ekspresije itd). Rezultati istraživanja pokazuju da se samo $7 \%$ emocionalnog komuniciranja prenosi riječima, 38\% korištenjem prozodijskih elemenata (intonacija, naglasak, ton, visina, jačina glasa, dikcija itd), a 55\% raznovrsnih emocionalnih poruka prenosimo neverbalnim znakovima $\mathrm{i}$ "govorom tijela" (body language), gestovima, izrazom lica. Ukoliko nije usklađena verbalna poruka sa neverbalnim sredstvima, prije ćemo povjerovati ovim drugima.

Komunikacija može biti:

- jednosmjerna (npr. objavljivanje sadržaja na webu, ili objavljivanje knjige, emisija na radiju ili televiziji, bez kontakta $\mathrm{s}$ primaocima);

- dvosmjerna (razgovor udvoje, komunikacija u grupi ili u razredu).

Tri su osnovna oblika komunikacije:

1. "JA" - "JA" - intrapersonalna komunikacija (subjekat je obavlja sam sa sobom kad razmišlja o nečem, rješava problem, piše dnevnik i sl. Odvija se neprestano, čak i kad sanjamo). 
2. "JA" - "TI/ON" - interpersonalna komunikacija (odvija se između dvije ili više osoba; dijalog u okviru grupe ili između više grupa).

3. "JA" - "VI/ONI" - masovna komunikacija uključuje velik broj učesnika i odvija se između više grupa ( Brajša, 1993.)

U ovim slučajevima osnovno sredstvo komunikacije je jezik, a to je verbalna komunikacija. Tokom verbalne komunikacije mogu se javiti i smetnje u komunikacijskom kanalu, i to se zove šum. Svaka komunikacija uključuje: pošiljaoca poruke (receptora), komunikacijski kanal za prenošenje poruke, poruku i primaoca poruke (recipijenta).

Dobra komunikacija uključuje: govor s kratkim, jasnim i direktnim rečenicama; kreativno konfrontiranje; ohrabrivanje i rješavanje problema; traženje dodatnih razrješenja; postavljanje pitanja, ukoliko nije jasno šta druga strana želi reći; održavanje direktnog kontakta očima sa drugom stranom; vođenja računa o govoru tijela; empatija i otvorenost; ohrabrivanje govornika da nastavi sa izlaganjem; sumiranje svojim riječima onoga što je govornik rekao i parafriziranje; postavljanje pitanja itd.

U ovom radu ćemo se usmjeriti na komunikacijski okvir između učenika, nastavnika i roditelja.

\section{Učitelj / nastavnik - učenik}

Odnosi između učitelja i učenika u toku odgojnog i obrazovnog procesa mogu biti međusobno ravnodušni. Nastavnici i učenici se mogu međusobno mrziti, voljeti, podnositi, mogu jedni druge odbacivati, prihvatiti i ne obazirati se jedni na druge; mogu se međusobno izbjegavati, susretati i mimoilaziti. U toku odgoja i izobrazbe, možemo razlikovati sadržajno slaganje i neslaganje između nastavnika i učenika s jedne, te njihovo međusobno prihvaćanje i odbacivanje, s druge strane.

Nastavnici i učenici mogu se međusobno slagati na nivou odgojno obrazovne poruke, ali i međusobno prihvatati na nivou međusobnog odnosa - to bi bila idealna odgojno-obrazovna i školska harmonija. 
Nastavnici i učenici se mogu ne slagati na sadržajnom nivou, ali i na odnosnom odbacivati - što se vrlo rijetko dešava, i to je više izuzetak.

Učitelji i učenici mogu se ne slagati na nivou sadržaja, ali se i dalje međusobno prihvatati na nivou odnosa (demokratska i kreativna škola).

Nastavnici i učenici međusobno se slažu na nivou sadržaja, iako su njihovi međusobni odnosi poremećeni do odbacivanja (škola sa poremećenim međusobnim odnosima).

Nastavnici i učenici mogu se ne slagati na nivou sadržaja samo zato što se međusobno ne prihvataju na nivou odnosa. Nastavnici često svoje poruke prilagođavaju svojim simpatijama ili antipatijama prema pojedinim učenicima. Također, učenici koji ne vole svoje nastavnike često odbacuju njihove poruke, bez obzira na to da li im odgovaraju ili ne. Mnogi se predmeti ne uče zato što učenici ne vole one koji im predaju.

Nastavnici i učenici mogu se ne slagati na nivou sadržaja, pa se zbog toga i ne prihvataju na nivou odnosa. U takvoj školi, različitost mišljenja bitno utiče na međusobne odnose. Tu se protiv neslaganja na sadržajnom nivou borimo neprihvatanjem na nivou međusobnih odnosa. To negativno utiče na ciljeve i uspješnost odgoja i izobrazbe. To rade i nastavnici i učenici.

Nastavnici i učenici često se ne slažu na nivou sadržaja, jer zbog prisile ili potrebe moraju ostati u međusobnom odnosu. Škola je potrebna učenicima, jer žele dobiti diplomu, a učiteljima je izvor zarade i posao. Mnogi glume prihvatanje sadržaja zbog potrebe održavanja odnosa. To i nije situacija u kojoj se može odgajati i obrazovati (Brajša, 1993.).

\section{Nastavnici - roditelji}

Kao što sam i prije navela, roditelji su prvi učitelji, prvi i najznačajniji odgajatelji, modeli koji se oponašaju. Među roditeljima postoje velike individualne razlike. Razlikuju se po sposobnostima, značaju, temperamentu, interesima, starosti, socijalnom i ekonomskom statusu, nivou obrazovanosti itd. Za nastavnika je vrlo važno da te razlike prepozna, poštuje, da svakog od roditelja što bolje 
upozna i da na taj način prilagodi način komunikacije s obzirom na njegove posebnosti. Svaki roditelj najbolje poznaje svoje dijete. Nastavnik učenika poznaje po njegovom učenju i ponašanju uglavnom iz škole, dok roditelj poznaje djetetov cjelokupni razvoj od rođenja pa dalje. Roditelj je duboko emocionalno vezan za svoje dijete, i nekad u toj velikoj ljubavi prema njemu, mogu biti nekritični i nerealni, od djeteta se očekuje previše ili premalo. Vrlo često se dešava da ne primijete probleme koji se javljaju kod njihove djece. U zajedničkom razgovoru koji uključuje iskustva roditelja i nastavnika, lakše je analizirati problem, primijetiti promjenu, lakše je odgovoriti na mnoga nejasna pitanja - šta se može uraditi kod kuće? Šta u školi? A šta djeca mogu uraditi sama?

Ovo je značajno zajedničko područje djelovanja nastavnika i roditelja usmjereno ostvarenju jednog cilja - odgoj mlade ličnosti. Škola, kao odgojna i obrazovna ustanova, treba pomoći roditeljima u tom cilju. Odgoj u školi treba biti nadopuna, a ne nadomjestak obiteljskog odgoja. P. Diole, francuski novinar, zatražio je od odličnih učenika recept uspjeha. Na pitanje šta im je pomoglo da uspiju, 75\% ispitanih učenika je odgovorilo: "Prije svega atmosfera koja vlada u mojoj kući" (Marija Bratanić, 1993, str. 146.). Od emocionalne obiteljske klime ovise, ne samo uspjeh djeteta, već i njegovo odrastanje u zdravu ličnost. Zbog nepravilnog stava roditelja prema djetetu, nerazumijevanju njegova ponašanja i neadekvatnih odgojnih postupaka roditelja, već u predškolsko doba mogu se pojaviti klice neprilagođenog ponašanja koje u novim sredinama mogu naći plodno tlo i uzrokovati teže oblike neprilagođenosti.

\section{Koje su to zajedničke odgovornosti roditelja i škole?}

1. ostvarivanje ciljeva;

2. postići uspjeh u školi;

3. uvažavanje - poštovanje nastavnika i roditelja od strane djece, ali njihovo uvažavanje i poštovanje učenika;

4. iskrena i jasna komunikacija;

5. razumijevanje;

6. usaglašavanje; 
7. zajedničko planiranje i odlučivanje.

\section{Zašto je važna saradnja škole / nastavnika i roditelja?}

Škola mora pomoći roditeljima u njihovim odgojnim nastojanjima, zbog toga treba poznavati obiteljske prilike učenika. Naravno, i roditelji moraju biti voljni ostvariti saradnju i pri tom pružiti svoj maksimum. Saradnja se najbolje ostvaruje na relaciji roditelj - razrednik. Razrednik je glavni nosilac te saradnje, jer u sistemu razredne i predmetne nastave dosta bolje poznaje svoje učenike i njihovu ličnost doživljava cjelovitije. Kada dijete dođe u 6 . razred, situacija se mijenja. Sada ima dosta nastavnika koji ga poznaju samo sa aspekta svog nastavnog predmeta, ocjenujući ga i vrednujući ga prema znanju i rezultatima u njegovim predmetima. Ličnost učenika kao cjeline se gubi. Sada se saradnja sa roditeljima svodi na formalne kontakte i roditeljske sastanke na kojima najčešće nisu prisutni roditelji one djece koja imaju najviše problema.

Također, saradnja škole i obitelji u velikoj mjeri zavisi od ličnosti razrednika, njegovoj angažiranosti i stavu prema roditeljima. Saradnja je interakcijski proces, pa i od stava roditelja zavisi hoće li razrednik biti manje ili više motiviran za saradnju (Grgin, 1997). Neki od tipova roditelja s kojima se nastavnici susreću:

- roditelji sa nerealnim očekivanjima (precjenjuju sposobnosti svog djeteta);

- nezainteresovani roditelji (ponekad roditelji ne posvećuju dovoljno pažnje svom djetetu ili njegovu obrazovanju. Dijete je prepušteno samo sebi i često odgojno zapušteno);

- roditelji sa pretjerano zaštitničkim stavom (uvijek će pomagati djetetu, čak i kad to uopće nije potrebno);

- roditelji sa socijalnom patologijom (alkoholizam, kleptomanija, narkomanija, prostitucija u obitelji). Ukoliko se otkrije treba ostvariti kontakt sa službom za socijalni rad, napraviti procjenju stanja, kako bi se donijele odluke o budućim koracima u uspostavljanju dobrog okruženja za dijete); 
- roditelji bez autoriteta (neki roditelji ne uspiju izgraditi autoritet $\mathrm{u}$ dječijim očima, pa ta djeca mogu imati određene probleme u ponašanju);

- roditelj sa mentalnom zaostalošću (s takvim roditeljima nekad može biti teško uspostaviti saradnju, ali učitelj treba dati sve od sebe. Interesantno je da obično ti roditelji pokazuju veliku zainteresiranost za svoje dijete. Zadatak učitelja je da njihovu pažnju usmjeri u pravom smjeru).

Nekad stav roditelja može biti nepovjerljiv i negativan prema školi već od ranije. Može biti uzrokovan na osnovu vlastitog iskustva roditelja tokom njihovog školovanja ili iz prethodnog razdoblja saradnje u vrtiću ili kasnije u školi. Nastavnik, tj. razrednik ne treba se osjećati povrijeđenim, već treba nastojati da razumije roditelja, te da pokuša da se adekvatno postavi prema njima i na taj način stvori osjećaj povjerenja i zainteresovanost roditelja za saradnju. U toj kategoriji roditelja najčešće se nalaze oni kojima je najviše potrebna pedagoška pomoć škole. To su roditelji čija su djeca lošijeg ponašanja i slabijeg uspjeha. Ponekad je teško uspostaviti saradnju i sa onim roditeljima koji misle da su se oslobodili odgovornosti odgajanja svog djeteta njegovim polaskom u školu. Vrlo često su to društveno angažirani roditelji, pa u tome nalaze opravdanje za takav stav. I ne trude se da sarađuju sa školom, a kad dijete doživi neuspjeh u učenju ili ponašanju, reaguju na neprikladan način i okrivljuju školu kao jedinog uzročnika tih problema. Kako razrednik da se postavi u takvim situacijama? Ne treba vraćati istom mjerom, već se treba empatično postaviti i pružiti im mogućnost za njihovo društveno angažiranje i na tom planu. Višestruki su zadaci koji se postavljaju pred saradnju roditelja i škole: roditelja;

- pedagoško obrazovanje i podizanje pedagoške kulture

- koordiniranje i usklađivanje odgojnog djelovanja obitelji i škole;

- nadoknada deficijentnog odgojnog djelovanja obitelji i škole (Bratanić, 1993).

Da bi se realizirali zadaci koji se odnose na podizanje pedagoške kulture roditelja, moraju biti u skladu s obrazovnim nivoom roditelja, 
psihofizičkim razvojem učenika, odgojnim potrebama i problemima obitelji. Škola nedovoljno posvećuje pažnju tim problemima, te se i ostvarenje tih zadataka odvija dosta nesistematski, nepovezano tokom jednog perioda školovanja i prepušteno je volji pojedinog razrednika u kojoj će mjeri te zadatke ostvariti. Bilo bi od velikog značaja da se ta saradnja i realizovanje zadataka koji se odnose na podizanje pedagoške svijesti roditelja mora zacrtati na planu škole tokom dužeg vremenskog perioda, te da se tokom određenog perioda vrši evaluacija napretka i ostvarenih ciljeva.

\section{Oblici saradnje koji se pojavljuju u odgojnoj praksi}

Roditeljima treba omogućiti da budu aktivni sudionici procesa obrazovanja, da aktivno govore i raspravljaju o problemima koji ih muče, da upoznavaju iskustva drugih roditelja. Važno je da roditelj dobije informacije $\mathrm{i}$ da dođe do određenih spoznaja koje će mu pomoći da osvijesti svoju ličnost, svoj odnos prema djetetu, odnose u obitelji, da ga te spoznaje motiviraju da posegne za literaturom koja će mu biti od koristi. Šta roditelj ima od pasivnog primanja gotovih informacija koje nije u mogućnosti direktno primijeniti u praksi?

Najvažniji i najveći dio saradnje provodi se u razrednim zajednicama i odjeljenjima, te razrednikovi programi koji se odnose na saradnju moraju biti što konkretniji. U programu, razrednik treba jasno sagledati osnovni cilj i zadatak saradnje, zacrtati oblike i sadržaj, te razne načine i mogućnosti realiziranja.

Neki od učestalijih oblika saradnje koji se pojavljuju u odgojnoj praksi su:

- individualni razgovori - informativni razgovor koristi razrednik da obavijesti roditelje o dostignuću, ponašanju i drugim osobinama učenika. (Uglavnom se svodi na čitanje ocjena);

- savjetodavni razgovori - ima za cilj razmatranje određenog problema i nalaženje adekvatnog odgojnog rješenja. Rijetko se provodi. Za ovu vrstu razgovora razrednik se treba unaprijed pripremiti i trebao bi se usmjeriti na realizaciju određenih pedagoških zadataka, bazirati se na uzajamnoj saradnji i komunikaciji;

- roditeljski sastanci - tu se može govoriti o problemima razreda, i može biti susret za pedagoško obrazovanje roditelja; 


\section{- posjet roditeljskom domu; \\ - pismeno obavještavanje.}

\section{Koristi od uključivanja roditelja}

Saradnja porodice i škole doprinosi aktiviranju i osposobljavanju roditelja za pedagošku djelatnost, omogućuje im uvid u ono što škola radi, koliko joj je i kako je moguće pomoći. Škola omogućuje roditeljima uvid u njene rezultate, propuste i nastojanja. Škola upoznaje roditelje sa reformama, ukazuje roditeljima na neophodnost rješavanja svih odgojnih problema u skladu sa ciljevima i zadacima školstva. Možemo zaključiti da bez prisne, sadržajno bogate i planski usmjerene saradnje porodice i škole, ne može biti govora o punom uspjehu u odgoju mladih, razvijanju svestrano obrazovanih, stvaralačkih i slobodnih ličnosti. Znači, koristi od uključivanja roditelja su mnogobrojne:

- povoljan uticaj na učenje djece, a time i na bolji uspjeh i ponašanje;

- stalno praćenje rada i razvoja učenika;

- zajedničko i uspješnije sagledavanje i otklanjanje eventualnih poteškoća koje usporavaju razvoj;

- sprječavanje raznovrsnih pojava preddelikventnog i delikventnih ponašanja.

Zajednički kontinuirani rad ima prednosti za nastavnike, roditelje i djecu. Nastavnik stiče kompletniju sliku o djetetu, a roditelj će dobiti informacije o ponašanju djeteta u školskoj/porodičnoj sredini, motivima učenika, sposobnostima, radnim navikama, načinu učenja i sticanja znanja, eventualnoj darovitosti učenika itd.

\section{Koje prednosti imaju učenici od saradnje njihovih roditelja $i$ nastavnika?}

1. osjećaj da nisu prepušteni sami sebi;

2. više $i$ slobodnije razgovaraju $i$ sa roditeljima $i$ sa nastavnicima;

3. imaju bolje ocjene i veću prolaznost; 
4. više prisustvuju nastavi;

5. imaju više motivacije i samopouzdanja;

6. manje posežu za drogom i alkoholom.

Međutim, nekad dolazi do izbjegavanja saradnje od strane roditelja. Neki od razloga mogu biti:

- pojedinim roditeljima treba ohrabrenja da dođu u školu;

- pojedini roditelji dolaze u školu samo po pozivu;

- pojedini roditelji nose sa sobom loša iskustva iz perioda svog školovanja, što stvara atmosferu u kojoj je nemoguće razviti partnerski odnos;

- neki roditelji smatraju da im nastavnici ne pružaju dovoljno pažnje;

- neki smatraju da nije dobro suprostavljati se nastavniku jer "on zna najbolje", "zamrzit će mi dijete" i sl.

\section{Metode}

\section{Hipoteze}

Osnovna hipoteza je da utvrđivanjem razloga loše komunikacije između nastavnika, roditelja i učenika, možemo doći do važnih saznanja koja će im pomoći u poboljšanju odnosa, saradnje, razvijanju kvalitetnije komunikacije, a što će na kraju rezultirati i boljim uspjehom đaka $u$ nastavnom procesu, te doprinijeti povećanju zadovoljstva nastavnika i roditelja.

Da bi bilo jasnije šta ćemo dobiti analizom rezultata ovog istraživanja, ovu generalnu hipotezu ćemo razložiti u nekoliko postavki:

Prvo, očekuje se da roditelji zadovoljniji saradnjom sa školom imaju i uspješniju djecu.

Drugo, nastavnici zadovoljniji saradnjom sa roditeljima ulažu više truda da što kvalitetnije prenesu znanja učenicima.

Treće, učenici koji imaju povjerenje u svoje nastavnike i roditelje su uspješniji u školi. 


\section{Uzorak}

Uzorak je obuhvatio grupu nastavnika, učenika i roditelja. Nastavnici i učenici su dio kolektiva osnovne škole "Harmani I", Bihać, a u anketnom istraživanju je učestvovalo 16 nastavnika, 38 roditelja i 47 učenika osmih razreda. Uzorak nije ujednačen po spolu, jer obuhvata 65 žena i 35 muškaraca. Također, uzorak je dosta malen i nije dovoljno reprezentativan za cijelu školu, ali može biti od koristi za uvid u stanja koja su prisutna u školama na ovim područjima, kao i podstrek za nova i opsežnija istraživanja.

\section{Instrumenti}

Za istraživanje se koristila anketa koja se sastojala od sedam pitanja upućenih roditeljima, nastavnicima i đacima (Bratanić, 1993.).

Anketnim istraživanjem se htjelo odgovoriti na nekoliko pitanja, kao što je pitanje saradnje škola/nastavno osoblje - roditelj, koje zamjerke imaju jedni prema drugima, na koji način smatraju da je moguće poboljšati tu saradanju (i za roditelje i za nastavnike) itd.

Izdvojena su pitanja koja nam mogu pomoći da se usmjerimo na njih na način da stručni tim škola usmjeri svoje potencijale i na razradu strategije kako poboljšati saradanju sa roditeljim, kako poboljšati kvalitet odnosa i zadovoljstvo na sve tri strane: učenici nastavnici - roditelji. Neka od tih izdvojenih pitanja su razrađena $u$ dijelu Rezultati istraživanja.

\section{Rezultati istraživanja i diskusija}

Tabela 1: Kako biste ocijenili saradnju sa školom

$\begin{array}{llllll}\begin{array}{l}\text { Ocjena } \\ \text { saradnje }\end{array} & 5 & 4 & 3 & 2 & 1 \\ \begin{array}{l}\text { Broj } \\ \text { procjena }\end{array} & 10 & 10 & 11 & 4 & 3\end{array}$

* Odgovori roditelja $(N=38)$

Iz rezultata koji su dati u tabeli možemo zaključiti da je većina roditelja (njih 31) relativno zadovoljna saradnjom sa nastavnicima/školom (u nastavku teksta podrobnije opisano). 
Tabela 2: Kako biste ocijenili saradnju sa roditeljima

$\begin{array}{llllll}\begin{array}{l}\text { Ocjena } \\ \text { saradnje }\end{array} & 5 & 4 & 3 & 2 & 1 \\ \begin{array}{l}\text { Broj } \\ \text { procjena }\end{array} & 0 & 7 & 8 & 0 & 1 \\ \quad * \text { Odgovori nastavnika }(N=16) & \end{array}$

\section{Razlozi za date ocjene}

Roditelji - pozitivni odgovori:

- trud nastavnika da što bolje poduče djecu;

- saradnja sa razrednicima;

- saradnja je odlična;

- nastavnici na vrijeme obavijeste roditelje o uspjehu i vladanju djece;

- smatram da je dijete sigurno u školi;

- zadovoljna sam sa sardanjom, jer ni ja više ne ulažem u tu saradnju;

Roditelji - negativni odgovori:

- pojedini nastavnici nemaju dovoljno znanja i ne pomažu učenicima;

- slaba komunikacija razrednika, roditelja, nastavnika i učenika;

- loš odnos nastavnika i djece;

- škola treba uvesti više discipline;

- Zbog nestručnosti većine nastavnika, zbog neadekvatnog pedagoškog sistema, zbog nezainteresovanosti nastavnika;

- Nedostatak saradnje i razumijevanja;

Zamjerke nastavnicima:

- Nemotiviranost, neki su potpuno nestručni, jer djecu pokušavaju umiriti sa jedinicama;

- Previše blagi prema djeci;

- Neki nastavnici nemaju iste kriterije prema učenicima istog znanja; 
- Prilikom ocjenjivanja se orjentišu prema ocjenama iz drugih predmeta;

- Do nekih nastavnika je teško doći;

- Nastavnici moraju vratiti autoritet;

- Pojedinim nastavnicima zamjeram zato što ponižavaju učenike i nisu realni u ocjenjivanju;

- Treniranje strogoće preko ocjena;

- Nastavnici nemaju dovoljno vremena za vježbanje $s$ učenicima, što je neophodno za njihovo znanje;

- Nema individualnog pristupa prema učenicima, pa i roditeljima, kao ni želje za saradnjom;

- Neki nastavnici previše očekuju, a premalo daju;

- Loše pripreme učenika za kontrolne radove..

Nastavnici - zamjerke roditeljima:

- Roditelji malo vremena posvećuju djeci, naročito što se tiče odgoja;

- Neki roditelji misle da kad pošalju dijete u školu tu prestaju sa svojim obavezama;

- Nekim roditeljima je sve "bistrije" nego njihovo dijete, npr. karijera;

- Pojedini roditelji dolaze samo kad se pojavi problem, a neki nikad;

- Pojedini roditelji dolaze neredovno na roditeljske sastanke;

- Govore glasno negativne stvari o školi i školstvu pred djecom;

- Zašto roditelji lično ne pitaju predmetnog nastavnika za razlog dobivene ocjene;

- Kod pojedinih neljubaznost, umišljenost, miješanje u posao nastavnika, neaktivnost;

Najčešće greške koje roditelji prave $u$ odgoju djece prema mišljenju nastavnika:

- Roditelji nisu zainteresovani za školu, već za zaradu;

- Ne potiču samostalnost kod djece; 
- Nedostatak pažnje prema djetetu, misle da mogu nadoknaditi kupovinom i neograničenom slobodom;

- Nedostatak interesovanja roditelja za uspjeh svoje djece;

- Nedovoljno savjetovanje i popustljivost, slijepo vjeruju djeci;

- Ne rade kontinuirano sa svojom djecom, već rade kad se nešto desi;

- Nedovoljno razvijene radne navike;

- "Moje dijete je bolje od druge djece";

- Slab interes, omalovažavanje značaja škole i školovanja, za njih je sve formalno;

- Previše demokratije u odgoju, prevelik džeparac, skupa tehnologija, odjeća..

- Zanemaruje se kućni odgoj;

- Ne odvajaju dovoljno vremena za svoje dijete, ne razgovaraju dovoljno sa svojim djetetom, previše vjeruju svom djetetu;

- Slaba posjećenost školi i interesovanje pojedinih roditelja;

- Nekad imaju i previše povjerenja u djecu, a sumnjanju u rad nastavnika na osnovu malo razgovora sa djetetom; Malo razgovaraju sa djecom;

- Ne uče ih da budu tolerantni, njihove obaveze (dječje) često uzimaju na sebe (spremanje školskih stvari).

Načini unaprijeđenja saradnje (prijedlozi roditelja):

- Više roditeljskih sastanaka;

- Obavještenje roditelju ako dijete ometa nasatvu;

- Više komunikacije između roditelja i nastavnika;

- Nastavnici trebaju biti realni prema svoj djeci, bez obzira ko su im roditelji;

- Više aktivnosti u kojima bi učestvovali i roditelji;

- Sastanci sa nastavnicima koji predaju predmete koji djetetu ne idu baš dobro, a ne samo sa razrednicima;

- Roditelji dosta utiču na obrazovanje svoje djece, pa najviše je na njima, zajedno sa nastavnicima, kako će uspjeti u tome;

- Motivacijom prosvjetnih radnika; veća plata;

- "Otvorena vrata" za razgovor sa upravom; 
- Češći dolasci roditelja na informativne sastanke;

- Strožije disciplinske mjere prema nemirnim i problematičnim učenicima..

Načini unaprijeđenja saradnje (prijedlozi nastavnika):

- Roditelji i nastavnici trebaju razviti partnerske odnose;

- Roditelji trebaju češće dolaziti u školu i biti u kontaktu sa školom;

- Neki roditelji se uključuju u razne projekte ako im se prezentuju na pravi način;

- Edukacija roditelja;

- Stalan protok informacija;

- Naučiti prihvatiti i kritiku;

- Više angažmana roditelja u kulturno-javnom životu škole;

- Savjetodavni rad sa roditeljima;

- Organizovati radionice sa roditeljima;

- Raditi na klimi međusobnog uvažavanja i povjerenja;

- Bolja saradnja socijalnih ustanova sa školom, a potreban je i psiholog koji bi, pored sa djecom, radio i sa (pojedinim) roditeljima;

- Roditelji moraju razgraničiti šta je njihova obaveza, a šta obaveza škole i ponašati se u skladu s tim..

Što se tiče saradnje na relaciji nastavnik - roditelj, uviđamo da postoji dosta kritika sa i za obje strane, a to trebamo iskoristiti za poboljšanje postojećeg stanja, jer se ne može napredovati ukoliko nam se ne ukažu naše pogreške, mane i nedostaci. I nastavnici i roditelji imaju pred sobom ozbiljan zadatak: da proanaliziraju sve ove kritike, da pronađu najbolji način kako se poboljšati, jer nam je to svima zajednički interes, da bi bili od pomoći našim mladima, našoj djeci, tj. đacima koji su najvrijedniji i najveći kapital! Iako je u ovoj anketi učestovao malen broj ispitanika, ipak sve ove sugestije ne treba potcjenjivati, već shvatiti ozbiljno i ozbiljno i pristupiti saniranju i rješavanju postojećih problema, da oni ne postanu još veći $i$ komplikovaniji. Na nastavnom je osoblju škole da osmišlja razne projekte u koje će uključivati roditelje, a na roditeljima je da, za 
dobrobit svoje djece, promijene svoje navike i da se više potrude pomoći nastavnicima u odgoju i izobrazbi djece.

Učenike se pitalo koje osobine cijene kod svojih nastavnika, šta utiče na stvaranje pozitivnog stava učenika prema nastavniku, ili koja ponašanja uzrokuje nerazumijevanje između nastavnika i učenika, kome se najčešće obraćaju za pomoć ukoliko imaju problema itd.

1. Koje osobine najviše cijeniš kod nastavnika? Učenici $(\mathrm{N}=47)$ su dali slijedeće odgovore:

- hladnokrvnost, pravednost u ocjenjivanju, pomažu pri učenju, dobro objašnjavanje gradiva, poštenje, saradnja, dobra komunikacija, ravnopravnost, dobrota, humor;

2. Šta uzrokuje nerazumijevanje između nastavnika i učenika?

- neodgovornost učenika; ocjene, nemirni i neposlušni učenici; nepravedno ocjenjivanje; nerazumijevanje problema učenika od strane nastavnika; ne poštuju učenikovo mišljenje; ne sasluša se učenika do kraja; kada se nastavnici drže za osobe višeg nivoa i kada se ne mogu postaviti u situaciju učenika.

3. Na pitanje da li su učenici zadovoljni sardnjom roditelja i škole, njih 27 je zadovoljno, dok je 18 nezadovoljno, a većina učenika je zadovoljna što roditelji sarađuju sa školom, te tako imaju uvid u njihove ocjene i disciplinu.

Interesantni su njihovi odgovori koji se tiču kome se obraćaju za pomoć, jer najveći dio njih prvo se obraća razredniku i samo razredniku, zatim roditeljima, prijateljima i pedagogu škole. To se može tumačiti i njihovim uzrastom, obzirom da su to učenici osmih razreda, koji su već u pubertetu, te svoje probleme češće iznose osobama van kuće, nekome kome se dive i u koga imaju povjerenja, a u ovom slučaju to su razrednici koji se trebaju još više truditi da ih djeca gledaju ne samo kao svoje nastavnike, već i kao svoje prijatelje, nekog ko će im pomoći da oni postanu bolje osobe.

\section{Zaključak}

Komunikacija je ključ uspjeha u svim sferama života, a pogotovo kada se govori o obrazovanju i odgoju. Kada govorimo o komunikaciji u školi, rijetki su istraživači koji se dubinski bave ovom 
problematikom na našim prostorima (pogledati P. Brajša, Pedagoška komunikologija, 1993.), a obzirom na alarmantno stanje $u$ obrazovnom sistemu, to je nedovoljno. Nadam se da će ovaj skromni istraživački pothvat biti podstrek istraživačima da se podrobnije zabave ovom tematikom, te da će se raditi na implementaciji produktivnih rješenja u cilju poboljšanja komunikacijskog procesa $u$ školskom sistemu. Upravo i rezultati ovog istraživanja govore o potrebi rada na poboljšanju komunikacije, obrazovanja, odgoja, međusobnih odnosa.. Roditelji su pozvani i kompetentni da sudjeluju u odgoju i obrazovanju svoje djece zajedno sa nastavnim osobljem, jer svi imaju zajednički interes - dobrobit djece. Razvoj partnerstva mogu inicirati roditelji, jer dobrim odnosom sa ostalim roditeljima i razrednikom/com mogu razmijeniti iskustva i sigurno naučiti nešto novo i korisno za dalji odgoj svoje djece. Pozitivna komunikacija je vještina koja se uči cijeli život, a koju možemo učiti samo u kontaktima sa drugim osobama. Važno je njegovati dobre odnose sa svojim djetetom i ukućanima, jer u dobroj klimi, kako u školi, tako i kod kuće, dijete postaje više zainteresiran i uspješnije.

Za uspjeh djece u školi su jednako odgovorni kako nastavnici u školi, tako i roditelji u kući. Kada je dijete sretno i uspješno, roditelji su također zadovoljni i ohrabreni, jer osjećaju da su doprinijeli tom dobru.

Dakle, za razliku od uzajamnog nepovjerenja i okrivljavanja, zahvaljujući pozitivnoj komunikaciji koja se razvija i uči u partnerskim odnosima između kuće i škole, imamo dogovor, podršku i zadovoljne roditelje, nastavnike i sretnu djecu. Timski rad je neizostavno bitan, ne samo pri izradi plana uspostavljanja kvalitetene komunikacije sa roditeljima, nego i pri njegovoj realizaciji. Kada edukujete roditelje, informišete o mogućnostima i vidovima saradnje i komunikacije, i kada ih pravilno usmjerite i postavite jasne ciljeve izbjegnut ćete razne probleme koji su danas sve više evidentni u školama. "Um nije posuda koju treba napuniti, već vatra koju treba zapaliti." Neka nam ova mudra izreka bude podstrek da budemo uspješni kao nastavnici i kao roditelji, te da zajedno odgojimo, obrazujemo i potičemo ih u kreativnom razvoju i rastu u uspješnu djecu i kasnije u uspješne ljude, korisne članove našeg društva! 


\section{Literatura:}

1. Brajša, Pavao Pedagoška komunikologija Školske novine-Zagreb, 1993.

2. Bratnić, Marija Mikropedagogija Školska knjiga Zagreb, 1993.

3. Ćatić, R., Stevanović, M. Pedagogija Pedagoški fakultet Zenica, 2003.

4. Grgin, Tomislav Edukacijska psihologija Jastrebarsko: Naklada Slap, 1997. Interenet izvori:

5. http://portal.skola.ba posjećeno 09.04.2011.

6. http://www.funkymem.com/?fm-zona/3/mala-skola-komunikacije-01/842 posjećeno 09.04.2011.

7. http://www.andjeli-cuvari.com/neverbalna.html posjećeno 09.04.2011

8. http://portal.skola.ba/start/Portals/0/PROJEKAT.pdf posjećeno 09.04.2011. 
Nejra Nesimović - Khedr, prof.

\section{COMMUNICATION AND FEEDBACK BETWEEN STUDENTS, TEACHERS AND PARENTS}

\section{SUMMARY}

This paper is devoted to an analysis of communication between teachers and students on one side and parents on the other side. From this analysis, the question arises how to improve communication between the main actors in the educational process and to actively involve parents in the educational process? There are many reasons that affect the establishment of good communication. The effective value of communication can be achieved only when the actors in the exchange of information primarily think about the importance of what they say, the impact of the spoken words as well as the level of established mutual understanding of different views and opinions. The initial level of professional training for proper communication starts through educational process, but the more important and influential level for developing a culture of communication among children is definitely family.

In order for a better insight and understanding of the situation in our schools, a survey has been conducted whose results are given as an overview in the tables. An important finding of this study is that there is a need for greater participation of parents in the educational process. Also, research indicates that teachers need more cooperation with parents as well as a better cooperation and communication between teachers and students. Finally, research is useful for teaching practice, helps educators and psychologists detect problems in school and opens a series of questions for further research and action.

Keywords: communication, feedback, the effective value of information 
الأستاذة نيرة نسيموفيتش خضر

الاتصال والمعلومات العائدة بين التلاميذ، الأسـاتذة والآباء

\section{خلاصية البحث}

يتناول البحث تحليل الاتصال بين المدرس والتلميذ من جهة وبين الآباء من جهة أخرى. هناك أسئلة في هذا التحليل تفرض نفسها: كيف يمكن تحسين الاتصال بين

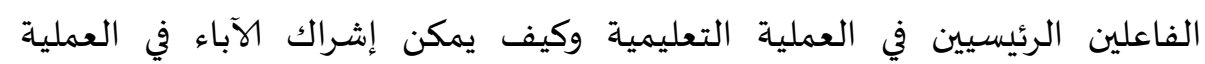

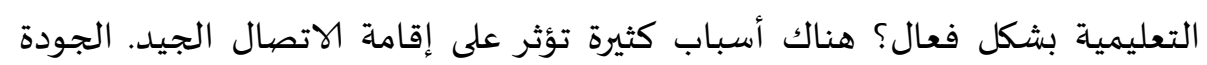

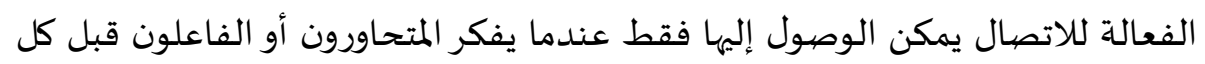

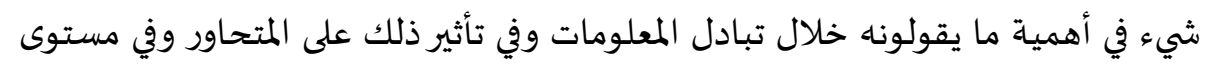

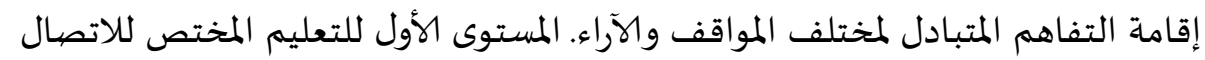

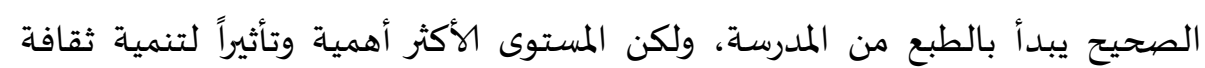

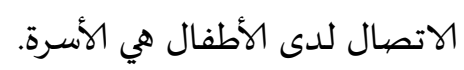

بهدف الإطلاع الأفضل وفهم الحال في مدارسنا قامت الباحثة باستطلاع الآراء

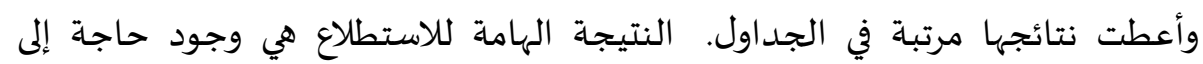

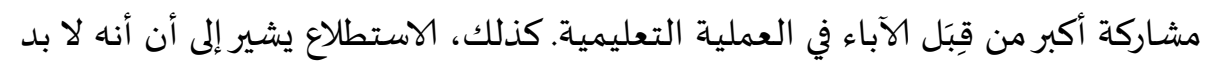

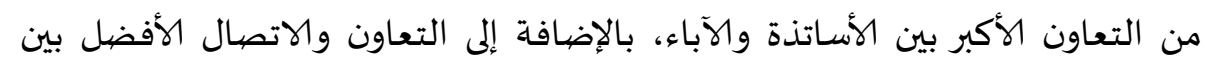
الأساتذة والتلاميذ.

في ختام، هذا البحث هام لممارسة التدريس التطبيقي، يسهّل لمدرسي علم

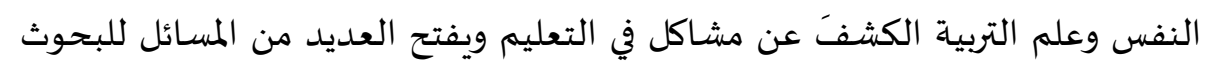
التالية والنشاط.

الكلمات الرئيسـة: الاتصال، المعلومات العائدة، القيمة الفعالية للمعلومة 